Duvel, J. W. T.

The vitality of buried seeds U.S.D.A., Bur. Plant Ind. Bull. 83. 22 p., $3 \mathrm{pl} ., 1 \mathrm{f} .1905$

QK

745

D985

1905

Bot. 


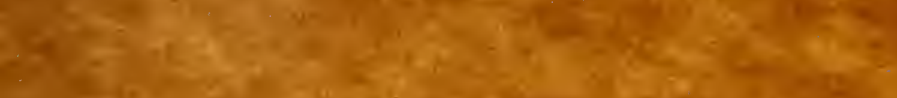

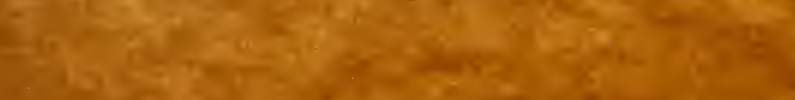

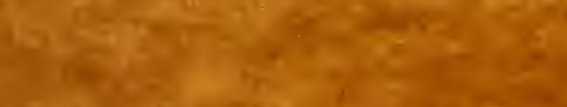

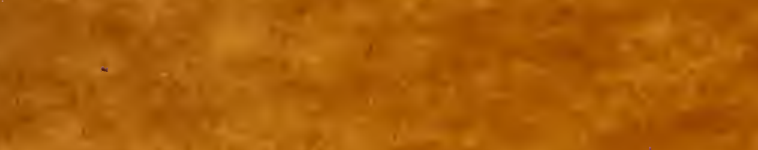

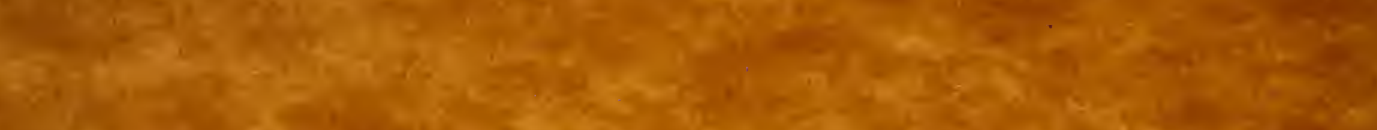

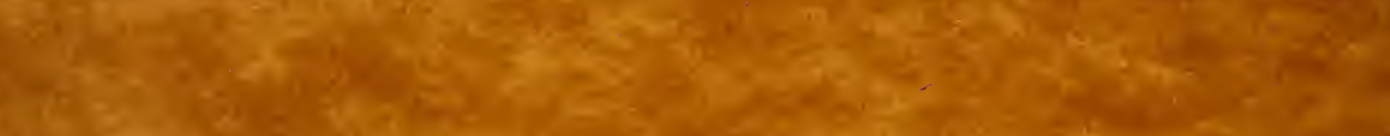

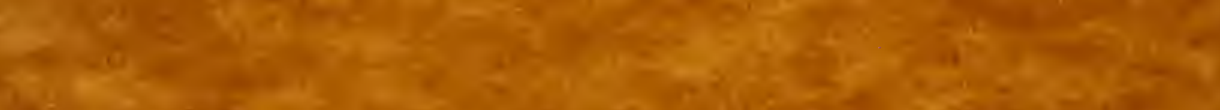

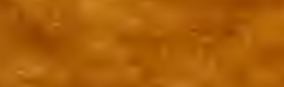

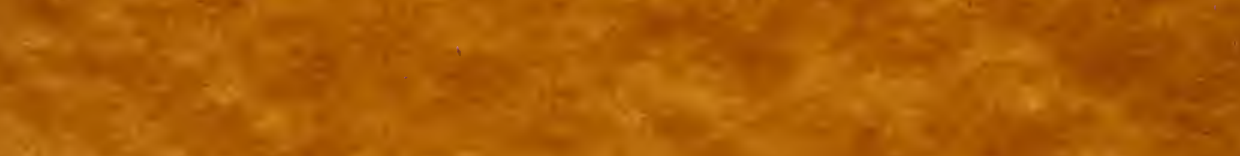

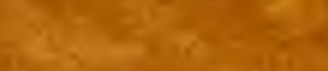

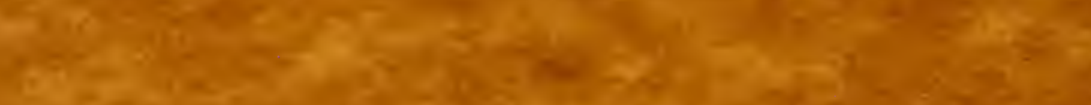

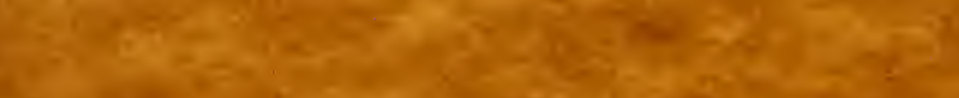

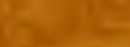

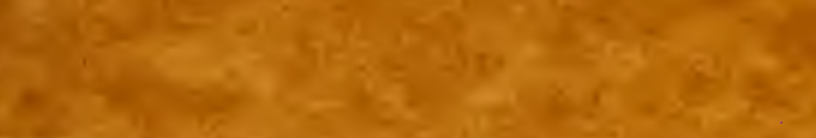

-

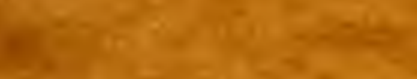

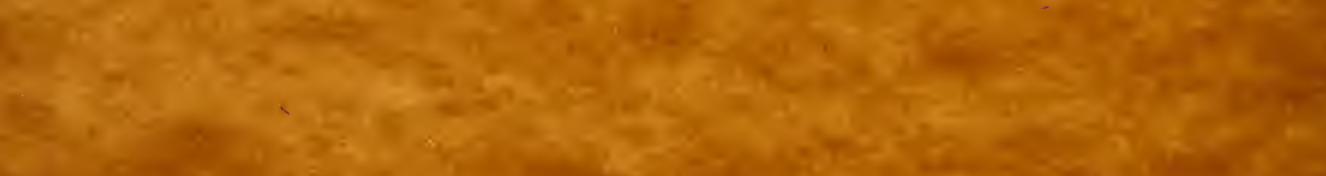
ats

30

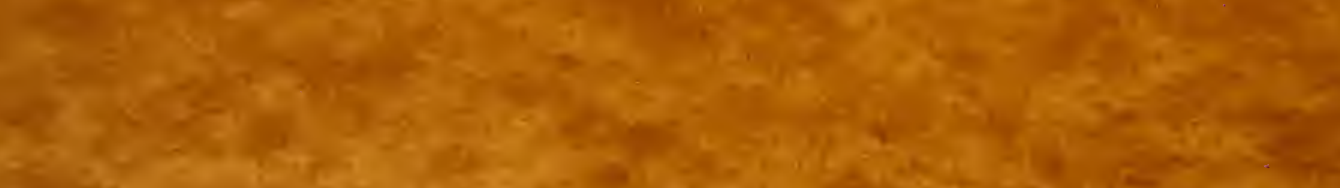

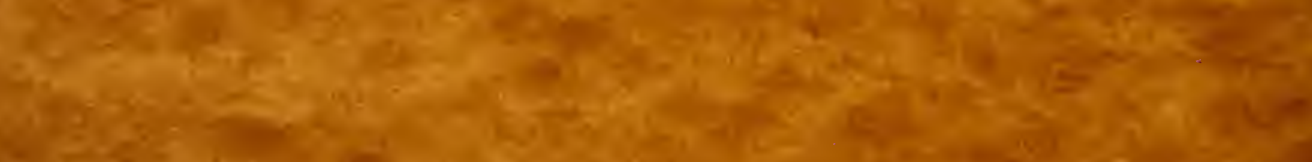

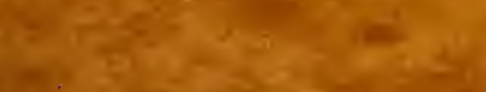

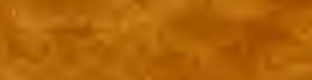




\section{BULLETINS OF THE BUREAU OF PLANT INDUSTRY.}

The Bureau of Plant Industry, which was organized July 1, 1901, includes Vegetable Pathological and Physiological Investigations, Botanical Investigations and Experiments, Grass and Forage Plant Investigations, Pomological Investigations, and Experimental Gardens and Grounds, all of which were formerly separate Divisions, and also Seed and Plant Introduction and Distribution, the Arlington Experimental Farm, Tea Culture Investigations, and Domestic Sugar Investigations.

Beginning with the date of organization of the Bureau, the several series of Bulletins of the various Divisions were discontinued, and all are now published as one series of the Bureau. A list of the Bulletins issued in the present series follows.

Attention is directed to the fact that "the serial, scientific, and technical publications of the United States Department of Agriculture are not for general distribution. All copies not required for official use are by law turned over to the Superintendent of Documents, who is empowered to sell them at cost." All applications for such publications should, therefore, be made to the Superintendent of Documents, Government Printing Office, Washington, D. C.

No. 1. The Relation of Lime and Magnesia to Plant Growth. 1901. Price, 10 cents.

2. Spermatogenesis and Fecundation of Zamia. 1901. Price, 20 cents.

3. Macaroni Wheats. 1901. Price, 20 cents.

4. Range Improvement in Arizona. 1902. Price, 10 cents.

5. Seeds and Plants Imported. Inventory No. 9. 1902. Price, 10 cents.

6. A List of American Varieties of Peppers. 1902. Price, 10 cents.

7. The Algerian Durum Wheats. 1902. Price, 15 cents.

8. A Collection of Fungi Prepared for Distribution. 1902. Price, 10 cents.

9. The North American Species of Spartina. 1902. Price, 10 cents.

10. Records of Seed Distribution and Cooperative Experiments with Grasses and Forage Plants. 1902. Price, 10 cents.

11. Johnson Grass. $1902 . \quad$ Price, 10 cents.

12. Stock Ranges of Northwestern California. 1902. Price, 15 cents.

13. Experiments in Range Improvement in Central Texas. 1902. Price, 10 cents.

14. The Decay of Timber and Methods of Preventing It. $1902 . \quad$ Price, 55 cents.

15. Forage Conditions on the Northern Border of the Great Basin. 1902. Price, 15 cents.

16. A Preliminary Study of the Germination of the Spores of Agaricus Campestris and Other Basidiomycetous Fungi. 1902. Price, 10 cents.

17. Some Diseases of the Cowpea. 1902 . Price, 10 cents.

18. Observations on the Mosaic Disease of Tobacco. 1902. Price, 15 cents.

19. Kentucky Bluegrass Seed. 1902. Price, 10 cents.

20. Manufacture of Semolina and Macaroni. 1902. Price, 15 cents.

21. List of American Varieties of Vegetables. 1903. Price, 35 cents.

22. Injurious Effects of Premature Pollination. 1902. Price, 10 cents.

23. Berseem. 1902. Price, 15 cents.

24. Unfermented Girape Must. 1902 . Price, 10 cents.

25. Miscellaneous Papers: I. The Seeds of Rescue Grass and Chess. II. Saragolla Wheat. III. Plant Introduction Notes from South Africa. IV. Congressional. Seed and Plant Distribution Circulars. 1903. Price, 15 cents.

26. Spanish Almonds. 1902. Price, 15 cents.

27. Letters on Agriculture in the West Indies, Spain, and the Orient. 1902. Price, 15 cents.

28. The Mango in Porto Rico. 1903. Price, 15 cents.

29. The Effect of Black Rot on Turnips. 1903. Price, 15 cents.

30. Budding the Pecan. 1902. Price, 10 cents.

31. Cultivated Forage Crops of the Northwestern States. 1902. Price, 10 cents.

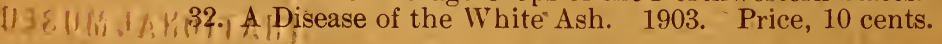

[Continued on page 3 of cover.] 
U. S. DEPARTIENT OF AGRICULTURE. BUREAU OF PLANT INDUSTRY - BULLETIN NO. 83.

B. T. GALLOWAI, (hief of Burcau.

\author{
T H E
}

\title{
VITALITY OF BURIED SEEDS.
}

BY

J. W. T. DUVEL,

Assistajt in the Seed Laboratory.

Issued Avgest 4, 1905.

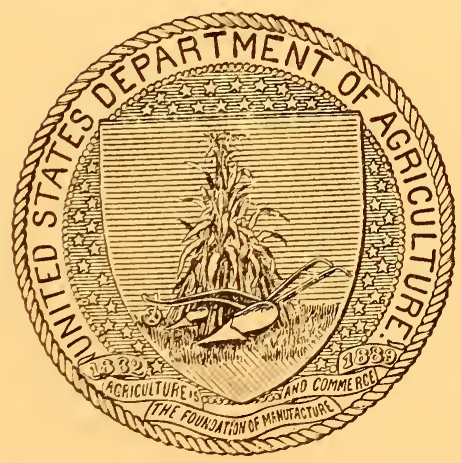

WASHINGTON:

GOVERNMENT PRINTING OFFICE.

$1 \div 05$. 


\section{BUREAU OF PLANT INDUSTRY.}

B. T. GALLOWAY,

Pathologist and Physiologist, and Chief of Bureau.

VEGETABLE PATHOLOGICAL AND PHYSIOLOGICAL INVESTIGATIONS.

Albert F. Woods, Pathologist and Physiologist in Charge, Acting Chief of Bureau in Absence of Chief.

BOTANICAL INVESTIGATIONS AND EXPERIMENTS.

Frederick Y. Coville, Botanist in Charge.

GRASS AND FORAGE PLANT INVESTIGATIONS.

IV. J. Spillmax, Agriculturist in Charge.

POMOLOGICAL INVESTIGATIONS.

(i. B. Brackett, Pomologist in Charge.

SEED AND PLANT INTRODUCTION AND DISTRIBUTION.

A. J. Preters, Botanist in Charge.

ARLINGTON EXPERIMENTAL FARM.

L. C. Corbett, Horticulturist in Churge.

EXPERIMENTAL GARDENS AND GROUNDS.

E. M. Brraes, Superintendent.

J. E. RockWell, Editor.

Janes E. Jones, Chirf Clerk.

SEED LABORATORY.

Scientific Staff.

Edgar Brown, Botanist in Charge.

F. H. Hillman, Assistant Botanist.

J. W. T. Duvel, Assistant. 


\title{
LETTER OF TRANSUITTAL.
}

\author{
U. S. Departuent of Agriculture, \\ Bureau of Plant Industry, \\ Office of the Chief, \\ Washington, D. C., May 29, 1905.
}

SIR: I hare the honor to transmit herewith, and to recommend for publication as Bulletin No. 83 of the series of this Bureau, the accompanying technical paper entitled "The Vitality of Buried Seeds."

The experiments discussed were undertaken in order to determine the length of time that seeds of different species of plants will retain their vitality when buried at various depths. Seeds of both cultivated and wild plants were used, but special attention was given to weed seeds in order to ascertain what weeds can be eradicated by deep plowing and how long the soil must remain undisturbed before the vitality of the seeds will be entirely destroyed. The results of the first year's experiments show that the noxious character of weeds is closely associated with the length of time the seeds will remain viable in the soil, and that many weeds can be eradicated by plowing. Much additional information is given, showing the relative resistance of the seeds of cultivated plants and of those commonly designated as weeds, and the influence upon the preservation of vitality of the depth of burial, of hard seed coats, and of hulled as compared with unhulled seed.

This paper was prepared by J. W. T. Duvel, Assistant in the Seed Laboratory, and has been submitted with a view to publication.

The accompanying illustrations are necessary for a complete understanding of the paper.

Respectfully,

Hon. James Wilson,

$$
\begin{aligned}
& \text { B. T. Galloway, } \\
& \text { Chief of Burean. }
\end{aligned}
$$

Secretary of Agriculture. 



\section{CONTENTS.}

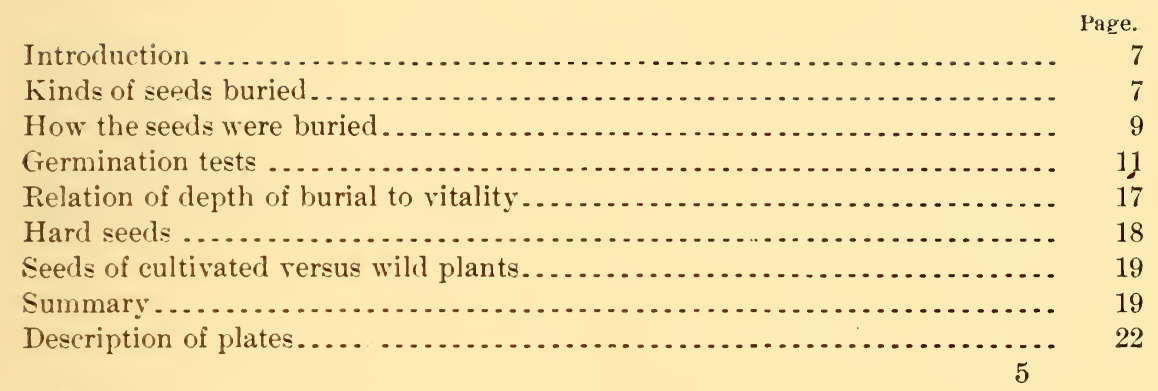




\section{ILLUSTRATIONS.}

PLATES.

Page.

Plate I. Fig. 1.-Bromus racemosu., smooth brome-grass. Fig. 2.-Bromus

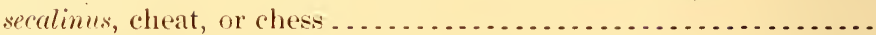

II. Fig. 1.-Alsine media, common chickweed. Fig. 2.-Rumex crispus, curled dock. Fig. 3.-Duturu tutula, jimson weed...............

III. Fig. 1.-Elymus canadensis, nodding wild rye. Fig. 2.-Fraxinus americana, white ash. Fig. 3.-Phytolacca americana, poke......

TEXT FIGITRE.

Fig. 1. Diagram showing order in which seets were buried............. . 10 


\section{THE VITALITY OF BURIED SEEDS.}

\section{INTRODUCTION.}

The preservation of the vitality of seeds when buried in the soil and the awakening of metabolic activity in such seeds on being exposed to conditions favorable to their germination are equally as important to the practical farmer as to the scientist. The intelligent farmer in order to combat noxious plants successfully should know how much time must elapse after heary crops of weeds of various sorts are turned under before the ground can be plowed again with safety. He should also know what plants he can hope to eradicate in this way, for with many of our worst weeds this method would result only in failure. In fact, the reason why the majority of our most persistent weeds are so difficult to eradicate is because their seeds are capable of retaining their vitality for a number of years when buried in the soil. It thus becomes important to know how different species of seeds behare when buried under similar conditions, and how seeds of the same species behave when buried under different conditions.

\section{KINDS OF SEEDS BURIED.}

So much has already been written on the germination of seeds that have remained dormant in the soil for a number of years, in some cases even for centuries, that it seemed desirable to determine with some degree of accuracy the length of time that certain seeds will retain their vitality when buried in the soil under known conditions. Accordingly, in the autumn of 1902, 112 different samples of seeds were selected for these experiments, as follows:

TABLE I. - List of seedls selerted for the experiments.

\begin{tabular}{|c|c|c|c|}
\hline $\begin{array}{l}\text { Labora- } \\
\text { tory } \\
\text { test } \\
\text { num- } \\
\text { ber. }\end{array}$ & Kind of seed. & $\begin{array}{l}\text { Sample } \\
\text { number. }\end{array}$ & $\begin{array}{l}\text { Burial } \\
\text { nunber } \\
\text { as given } \\
\text { on } \\
\text { diagram. }\end{array}$ \\
\hline $\begin{array}{l}16173 \\
16171 \\
16175 \\
16176 \\
16177 \\
16178 \\
16179 \\
16189 \\
161 \times 1 \\
161 \times 2 \\
16 i 1 \times 3 \\
161 \times i\end{array}$ & 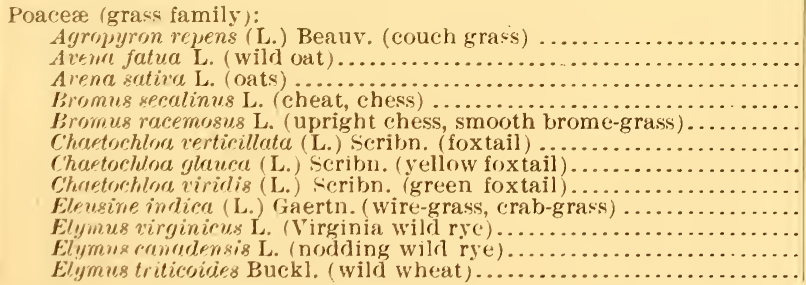 & $\begin{array}{r}100 \\
71 \\
24 \\
34 \\
33 \\
108 \\
46 \\
5 \\
26 \\
77 \\
74 \\
69\end{array}$ & $\begin{array}{r}31 \\
9 \\
8 \\
36 \\
37 \\
66 \\
33 \\
67 \\
72 \\
15 \\
13 \\
14\end{array}$ \\
\hline
\end{tabular}


TABLE I. - List of seeds selected for the experiments-Continued.

\begin{tabular}{|c|c|c|c|}
\hline $\begin{array}{c}\text { Labora- } \\
\text { tory } \\
\text { test } \\
\text { num- } \\
\text { ber. }\end{array}$ & Kind of seed. & $\begin{array}{l}\text { Sample } \\
\text { number. }\end{array}$ & $\begin{array}{c}\text { Burial } \\
\text { number } \\
\text { as given } \\
\text { on } \\
\text { diagram. }\end{array}$ \\
\hline & Poaceæ (grass family)-Continued. & & \\
\hline $\begin{array}{l}16185 \\
16186\end{array}$ & $\begin{array}{l}\text { Festuca elatior } \mathrm{L} \text {. (meadow tescue)... } \\
\text { Hordeum sativum Jessen. (barley)... }\end{array}$ & $\begin{array}{l}38 \\
23\end{array}$ & $\begin{array}{l}35 \\
12\end{array}$ \\
\hline 16187 & Panicum virgatum L. (tall, smooth panicum & 70 & 32 \\
\hline 16188 & Phalaris arundinacea L. (reed & 93 & 34 \\
\hline 16189 & Phleum pratense L. (timothy) ........... & 112 & 68 \\
\hline 16190 & Poa pratensis L. (Kentucky bluegrass)...... & 75 & 73 \\
\hline 16191 & 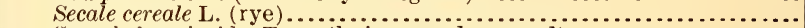 & 25 & 11 \\
\hline 16192 & Sporobolus airoides Torr. (hair-grass drop-seed) & 12 & 69 \\
\hline 16193 & Sporobolus cryptandrus (Torr.) A. Gray (sand drop & 63 & 71 \\
\hline 16194 & Sporobolus cryptandrus (Torr.) A. Gray (sand drop- & 13 & 70 \\
\hline 16195 . & Triticum aestivum. L. (wheat)........ & 22 & 10 \\
\hline 16196 & Zea mays L. (corn-Boone County white) & 14 & 1 \\
\hline 16197 & $\begin{array}{l}\text { Zea mays L. (sweet corn-early Concord)... } \\
\text { Cyperaceæ (sedge family): }\end{array}$ & 15 & 2 \\
\hline 16198 & $\begin{array}{l}\text { Cyperus esculentus L. (yellow nut-grass)... } \\
\text { Liliaceæ (lily family): }\end{array}$ & 7 & 74 \\
\hline 16199 & Allium cepa L. (onion) .................. & 27 & 39 \\
\hline 16200 & $\begin{array}{c}\text { Convallariaceæ (lily-of-the-valley family): } \\
\text { Asparagus officinalis } \mathrm{L} \text {. (asparagus) }\end{array}$ & 32 & 16 \\
\hline 16201 & $\begin{array}{l}\text { Moraceæ (mulberry family): } \\
\text { Cannabis sativa L. (hemp). } \\
\text { Urticaceæ (nettle family): }\end{array}$ & 4 & 17 \\
\hline 16202 & $\begin{array}{l}\text { Boehmeria nivea Gaud. (ramie) } \\
\text { Polygonaceæ (buck wheat family) }\end{array}$ & 2 & 75 \\
\hline 16203 & Fagopyrum fagopyrum (L.) Karst. (bu & 21 & 18 \\
\hline 16204 & Jolygonum pennsylvanicum $\mathrm{L}$. ( $\mathrm{Pe}$ & 9 & 40 \\
\hline 16205 & Polygonum persicaria L. (lady's- & 10 & 78 \\
\hline 16206 & Polygonum scandens $\mathrm{J}$. (climbing $\mathrm{f}$ & 11 & 41 \\
\hline 16207 & Rumex salicifolius Weinn & 107 & 76 \\
\hline 16208 & Rumex crispus L. (c & 103 & 39 \\
\hline 16209 & $\begin{array}{l}\text { Rumex obtusifolius L. (broad-leaved dock, bitter d } \\
\text { Chenopodiaceæ (goosefoot family): }\end{array}$ & 102 & 77 \\
\hline 16210 & Axyris amarauthoidles L. (Russian pigweed) & 1 & 81 \\
\hline 16211 & Beta vulgaris L. (sugar beet) & 72 & 19 \\
\hline 16212 & Chenopodium album L. (lamb's qu & 96 & 79 \\
\hline 16213 & Chemopdium hybridum L. (maple-leaved goosefoot). & 62 & 80 \\
\hline 16214 & Amaranthus retroflexus (rough pigweed)... & 83 & 82 \\
\hline 16215 & $\begin{array}{l}\text { Phytolaccace (pokeweed family): } \\
\text { Phytolacca americana L. (poke, pigeon berry). }\end{array}$ & 104 & 42 \\
\hline & Portulacaceæ (purslane family): & & \\
\hline 16216 & $\begin{array}{l}\text { Portulaca oleracea L. (purslane, pussley)..... } \\
\text { silenaceæ (pink family): }\end{array}$ & 86 & 3 \\
\hline 16217 & L. (corn cockle). & 16 & 43 \\
\hline 16218 & Alsine media $\mathrm{L}$. (er & 110 & 84 \\
\hline 16219 & $\begin{array}{l}\text { Vaccaria vaccaria (L.) Britton (cowherb)... } \\
\text { Brassicacex (mustard family): }\end{array}$ & 55 & 44 \\
\hline 16220 & Brassica nigra (L.) Koch (black mustard) & 67 & 87 \\
\hline 1 & Brassica oleracea L. (cabb: & 17 & 5 \\
\hline 16222 & is L. (t & 40 & 88 \\
\hline 16223 & Bursa bursa-pastoris (L.) Br & 3 & 89 \\
\hline 16224 & Erysimum cheiranthoides $\mathrm{L}$. & 58 & 47 \\
\hline 16225 & Neslia paniculata (L.) Desv. & 85 & 46 \\
\hline 16226 & Sisymbrium altissimum $\mathrm{L}$. (tall sis. & 78 & 00 \\
\hline 16227 & $\begin{array}{l}\text { Thlaspi arvense } \mathbf{l} \text {. (field penny cress) .............. } \\
\text { Rosaceæ (rose family): }\end{array}$ & 60 & 85 \\
\hline 16228 & Potentilla monspeliensis L. (rough cinquefoil) & 73 & 90 \\
\hline 16229 & Cassia marylandica L. (wild senna, American ser & 52 & 48 \\
\hline 16230 & $\begin{array}{l}\text { Fabaceæ (pea family): } \\
\text { Lespedeza frutescens (L.) Britton (wand }\end{array}$ & 43 & 52 \\
\hline 16231 & Medicago sativa $\mathrm{L}$. (alfalfa, lu & & 49 \\
\hline 16232 & garis L. (bean). & 20 & 4 \\
\hline 16233 & Pisum sativum L. (pea) .. & 19 & 5 \\
\hline 16234 & Robinia pseudacacia L. (loc & 37 & 51 \\
\hline 16235 & Trifolium hybridum L. ( & 50 & \\
\hline 16236 & Trifolium pratense $\mathrm{L}$. (red $\mathrm{C}$ & 49 & 50 \\
\hline & Trifolium pratense L. (red el & 54 & 91 \\
\hline 16238 & Trifolium pratense L. (red clover) hard seed from & 68 & \\
\hline 16239 & Trifolium repens $\mathrm{L}$. (white clover)..... & 41 & \\
\hline 16240 & 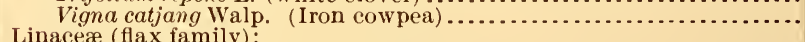 & 42 & \\
\hline 16241 & Linum usitatissimum L. (flax, linseed). & 30 & 53 \\
\hline $1624^{\circ}$ & Anacardiaceæ (sumac family): & 47 & 2 \\
\hline & Malvaceæ (mallow family): & & \\
\hline 16243 & Abutilon abutilon (L.) Rusby. & 111 & 54 \\
\hline 1624 & Gossypium hirsutum L. (cotton).. & 18 & \\
\hline & Hibiscus militaris Cav. (halberd-1 & 31 & \\
\hline
\end{tabular}


TABLE I. - List of seeds selected for the experiments-Continued.

\begin{tabular}{|c|c|c|c|}
\hline $\begin{array}{c}\text { Labora- } \\
\text { tory } \\
\text { test } \\
\text { num- } \\
\text { ber. }\end{array}$ & Kind of seed. & $\begin{array}{l}\text { Sample } \\
\text { number. }\end{array}$ & $\begin{array}{c}\text { Burial } \\
\text { number } \\
\text { as given } \\
\text { on } \\
\text { diagram. }\end{array}$ \\
\hline $162+6$ & Hypericacee (St. John's wort family): & 44 & \\
\hline & Onagraceæ (evening prim rose family): & & \\
\hline $16: 4 i$ & $\begin{array}{l}\text { Onagra biennis (L.) Scop. (common evening primrose) .. } \\
\text { Apiacere (carrot family): }\end{array}$ & 8 & 96 \\
\hline 16248 & 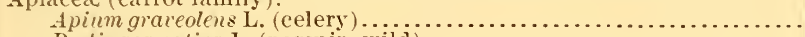 & 94 & \\
\hline 16249 & $\begin{array}{l}\text { Pastinaca satira L. (parsnip, wild) } \ldots \ldots \ldots \ldots \ldots \ldots \ldots \ldots \ldots \ldots \ldots \\
\text { Oleaceæ (olive family): }\end{array}$ & 95 & 66 \\
\hline 16250 & $\begin{array}{l}\text { Fraxinus americana L. (white ash) } \ldots \ldots \ldots \ldots \ldots \ldots \ldots \ldots \ldots \ldots \\
\text { Convolvulacere (morning-glory family): }\end{array}$ & 105 & 21 \\
\hline $\begin{array}{l}16251 \\
16252\end{array}$ & $\begin{array}{l}\text { Concolvulus sepium L. (hedge bindweed, great bindweed). } \\
\text { Ipomoea lacmosa L. (small-flowered white morning-glory) }\end{array}$ & $\begin{array}{l}56 \\
81\end{array}$ & $\begin{array}{l}23 \\
22\end{array}$ \\
\hline & Cuscutaceæ (dodder family): & & \\
\hline $\begin{array}{l}16253 \\
16254\end{array}$ & $\begin{array}{l}\text { Cuscute polyponorum Engelm. (smart } \\
\text { Cnscuta epilinum Weihe. (flax dodde }\end{array}$ & $\begin{array}{l}63 \\
82\end{array}$ & \\
\hline & Verbenaceæ (vervain family): & & \\
\hline 1625.5 & Terbena hastata L. (blue verv & .66 & 100 \\
\hline 162.00 & $\begin{array}{l}\text { Verbena urticifolia L. (white vervain, nettle-leav } \\
\text { Solanaceæ (potato family): }\end{array}$ & 79 & \\
\hline 16257 & Copsicum annuum L. (red pepper & 39 & \\
\hline 16258 & Datura tatula L. (purple st & 106 & 61 \\
\hline $\begin{array}{l}16259 \\
16260\end{array}$ & L.ycopersicon lycopersicon (L.) Karst. (tomato) ........ & $\begin{array}{l}45 \\
99\end{array}$ & 60 \\
\hline 16261 & Solanum nigrum L. (black nightshade, garden nightshade) & 61 & 58 \\
\hline 16262 & $\begin{array}{l}\text { ophulariacex (figwort fan } \\
\text { Terbascum thapsus L. (gre }\end{array}$ & 76 & 102 \\
\hline & Plantaginacere (plantain family): & & \\
\hline 16263 & Plantago lancecolata L. (rib & 88 & 105 \\
\hline 16264 & Plantago major L. (comn & 91 & 103 \\
\hline & $\begin{array}{l}\text { Plantago rugulii Dec. (Rugel's plantain, broad plantain) ... } \\
\text { Cucurbitacere (gourd family). }\end{array}$ & 65 & 104 \\
\hline $16266^{\circ}$ & C'itrullus citrnllus (L.) Karst. (watermelon). & 6 & \\
\hline 16267 & Cucrmis mulo L. (muskmelon) & 26 & 25 \\
\hline 1626 & $\begin{array}{l}\text { Cncmmis sativns L. (eucumber) } \ldots \ldots \ldots \text {. } \\
\text { ('ichoriaceæ (chicory family): }\end{array}$ & 48 & \\
\hline 16269 & Lactnca scariola L. (prickly lettuce). & 98 & 107 \\
\hline 16270 & Lactuca sativa L. (lettuce)........ & 28 & 62 \\
\hline $162 \pi 1$ & $\begin{array}{l}\text { Toracacum erythrospermum Andrz. (red-secded dandelion) } \\
\text { Ambro-iaceæ ( ragweed family): }\end{array}$ & & 106 \\
\hline 16,272 & 1 mbrosia artemisiarfolia L. (rag & $87 \mathrm{P}$ & 63 \\
\hline & Ambrosia trifita L. (great ra & 53 & 28 \\
\hline & Asteracex (aster family): & & \\
\hline 16275 & Arrtium lappa L. (burdock, clotbu & 101 & 112 \\
\hline $16 \div 276$ & sa L. (bla & 84 & \\
\hline & Cardulis arcensis (L.) Robs. (Can & 80 & 111 \\
\hline $162-i x$ & Chrysanthemum leuconthemum L. (I) & 92 & 110 \\
\hline 16279 & Girindelia squarrosa (Pursh.) Dunal. (broad-leaved gum plant & 89 & 108 \\
\hline & Ilelianthus annuus L. (common sul & 97 & \\
\hline $162 \times 1$ & Helianthus anmus L. (common sunflower, eultiv: & 29 & \\
\hline $162 \times 2$ & Onopoirlon arranthium L. (cotton thistle, seoteh thistle) & 109 & \\
\hline & $\begin{array}{l}\text { Rurbeckin hirtu L. (black-eyed Susan) ............... } \\
\text { Pinaceæ (bine familv): }\end{array}$ & 57 & 109 \\
\hline 16244 & Pinus rirginiana yill. (srrub pine, Jersey pine). & 36 & 30 \\
\hline
\end{tabular}

\section{HOW THE SEEDS WERE BURIED.}

The foregoing list represents 109 species, 84 genera, and 34 families of plants. Carefully counted seeds of these samples were mixed with dry ray soil and packed in well-baked earthen pots (the common flowerpot used in greenhouses). The filled pots were covered with inverterl rlay saucers in order to prevent the seeds from being destroyed or becoming mixed with other seeds which might have been in the soil with which the pots were covered. By burying the seeds mixed with earth in porous clay pots of this character they were subjecterd to conditions almost identical with those which would exist if the reds were buried either accidentally or by natural causes. The profous clay pots admitted of the free circulation of air and water.

$30 \%, 5 \%$ f- Io. 8\%-0.5-2 
The pots containing these seeds were buried at three different depths. Eight complete sets were buried from 6 to 8 inches below the surface, being covered approximately the same as would result from deep plowing. Twelve complete sets were covered to a depth rarying from 18 to 22 inches, sufficiently deep in this latitude to be reasonably secure from the action of frost. 'Twelve more complete sets were buried at a depth varying from 36 to 42 inches where the conditions were nearly uniform, so far as the three factors which regulate the germination of seeds are concerned, namely, heat, moisture, and air (oxygen). Figure 1 shows the arrangement of the pots, which were of 6 -inch, $t$-inch, and 2 -inch sizes, to accommodate the different kinds of seed.

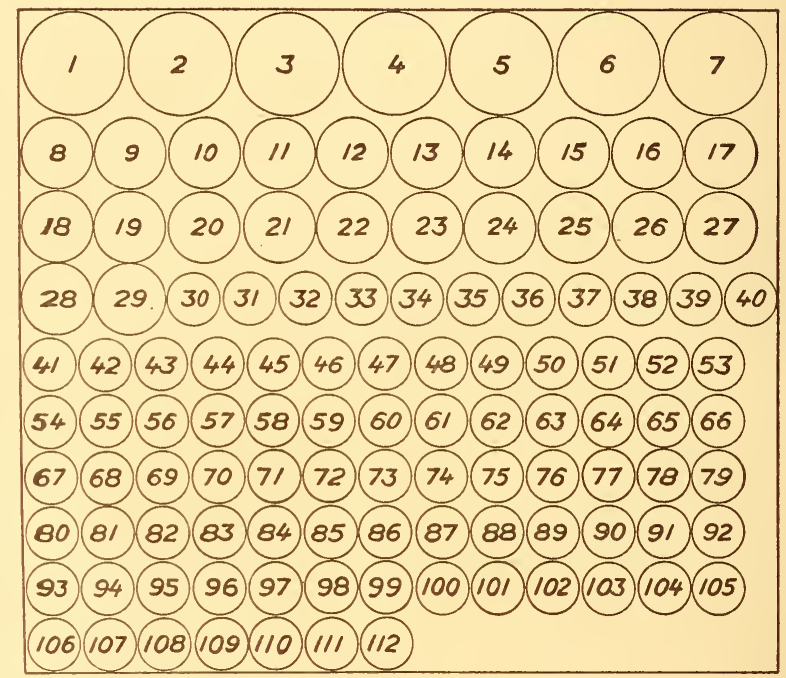

FIG. 1.-Diagram showing order in which seeds were buried.

These seeds were buried December 19 to 23, 1902, in a heavy clay soil on the Arlington Experimental Farm of the United States Department of Agriculture. With the exception of two of the duplicate samples of red clover, the seeds were of the harrest of 1902.

In each case a definite number of seeds was taken. Of the larger kinds. such as beans. peas, corn, etc.. 100 seeds were used, but for the majority of the samples 200 seeds were taken. The seeds selected were for the most part of plants with which the greater number of the farmers throughout the United States are more or less familiar, either as plants of economic importance or as weeds.

In all 32 complete sets, representing $3.58 t$ pots, were buried. One set from each of the three different depths is to be taken up as the conditions warrant and will be tested for vitality. The results of these tests are to be compared with the germination of seeds from the original bulk samples designated throughout this report as "controls." 
The control samples are heing stored in cloth bags in a dry room on the second floor of the seed Laboratory. The first complete series of three sets was taken up in Norember, 1903, eleven months after they had been buried. The results of the first year's experiment are given in the following pages.

\section{GERIIINATION TESTS.}

In making the germination tests of the buried seeds the contents of the pots, the mixture of seed and soil, were spread on sand in ordinary greenhouse flats. Along with these, in the same flats, were control samples taken from the criginal bulk lot of seeds, as preriously mentioned. In addition, another complete set of control samples was tested in the germinating chambers of the Seed Laboratory. The tem- " peratures giren in the ta 1 s are those best suited for the germination of the different seeds.

For conrenience the results of the germination tests have been divided into three grouns, as follows:

1. Seeds in which the control samples, as well as those that were buried. gare only negative results when tested in the greenhouse.

B. seeds which had either decayed or germinated and afterwards decayed while they were buried.

C. seeds which had not completely lost their vitality while buried.

The first group. i. e., those in which both the control samples and those which had been buried failed to germinate when planted in flats in the greenhouse, consists of the following species:

1. Aryris amaranthoides L. (Russian pigweed).

2. Boehmeria wiren Guad. (ramie).

3. Bursa bursa-pastoris (L.) Britton (shepherd's purse).

4. Canualis sutiva L. (hemp)).

5. Chaetorhlou riridis (L.) Scrilon. (green foxtail?

6. Citrullus citrullus (L.) Karst. (watermelon).

7. C'yperus esculentus L. (yellow nut-grass).

S. Onugira biemis (L.) Scop. (evening prinrose).

9. Polygonum pennsylcanicum L. (Pennsylvania smartweed, persicaria).

10. I'olygomm persicaria L. (larly's-thumb, smartweed).

11. I'olygrmum scundens L. (climbing false buckwheat).

12. Siporotrolus ritoides Torr. (hair-grass drop-seed).

13. Sporotolus cryptrudens (Torr.) A. Gray (sand drop-seed-hulled seed).

In this series the hemp should be discarded, as repeated tests failed to show any seeds from the bulk samples capable of germination. The control samples of the other seeds when tested in the germinating chambers germinated nearly as well and in some cases even better than the chamber tests which were made at the time the seeds were buried. Undoubtedly some of these seeds had decayed while buried in the soil; in fact, the watermelon seeds, Axyris amaranthoides, and Sporobolus airoirles were marked "mostly decayed" when taken up. Generally speaking, the results show that the failure to gem minate was not in the 
seeds, but that the conditions in the greenhouse were at fault, and until other tests are made these results can not be discussed with any degree of satisfaction. On the other hand, it is certain that some of the smaller seeds failed to germinate because they were covered too deeply when sown in the flats in the greenhouse.

Polygonum scandens possibly should be classified in Table III, inasmuch as some of the seeds which were buried at depths of from 18 to 22 inches and from 36 to 42 inches showed a few sprouts at the time the seeds were taken up, but after being transferred to the greenhouse no seedlings were developed. Howerer, the failure in the germination of the control sample of Polygonum scandens throws it into the first group (A) with the other two species of the same genus, i. e., Polygonum pennsyleanicum and P. persicaria.

The result of the tests of the buried seed of Sporobolus cryptandrus, as given in this group, should be compared with the germination of the unhulled seed as given in Table III, No. 6t. The control samples of both the hulled and the unhulled seed which were sown in the greenhouse failed to germinate, but all three samples of the unhulled seed that had been buried gave some germination when tested in the greenhouse.

TABLE II. - liesults of tests of seeds which had sither decayed or germinated and afteruards decayed while buried.

\begin{tabular}{|c|c|c|c|c|c|c|c|c|c|}
\hline \multirow{3}{*}{ 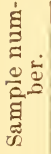 } & \multirow{3}{*}{$\begin{array}{c}\text { Labora- } \\
\text { tory } \\
\text { test } \\
\text { num- } \\
\text { ber. }\end{array}$} & \multirow{3}{*}{ Kind of seed. } & \multicolumn{3}{|c|}{ Chamber tests. } & \multicolumn{4}{|c|}{ Greenhouse tests in sand. } \\
\hline & & & \multirow{2}{*}{$\begin{array}{l}\text { Tem- } \\
\text { pera- } \\
\text { ture. }\end{array}$} & \multirow{2}{*}{$\begin{array}{c}\text { Origi- } \\
\text { nal } \\
\text { sample. }\end{array}$} & \multirow{2}{*}{$\begin{array}{l}\text { Con- } \\
\text { trol. }\end{array}$} & \multirow{2}{*}{$\begin{array}{l}\text { Con- } \\
\text { trol. }\end{array}$} & \multicolumn{3}{|c|}{ Depth of burial. } \\
\hline & & & & & & & $\begin{array}{c}6-8 \\
\text { inches. }\end{array}$ & $\mid \begin{array}{c}18-22 \\
\text { inches. }\end{array}$ & $\begin{array}{c}36-42 \\
\text { inches. }\end{array}$ \\
\hline 14 & 16196 & Zea mays (Boone County white & ${ }^{\circ} C$ & Per ct. & Per ct. & Per ct. & Per ct. & Per ct. & Perct. \\
\hline 15 & 16197 & $\begin{array}{c}\text { corn }) \ldots \ldots \ldots \ldots \ldots \ldots \ldots \\
\text { Zea mays (sweet corn) } \ldots \ldots \ldots \ldots\end{array}$ & $\begin{array}{l}20-30 \\
20-30\end{array}$ & $\begin{array}{l}99.5 \\
98.5\end{array}$ & $\begin{array}{l}99 \\
98.5\end{array}$ & & & & \\
\hline 16 & 16217 & Agrostemma githago. & $20-30$ & 99 & 98.5 & & & & \\
\hline 17 & 16221 & Brassica oleracea.... & 20 & 85. & 82 & & & & \\
\hline 18 & 16244 & Gossypium hirsutum & $20-30$ & 77. & 72 & & & & \\
\hline 19 & 16233 & Pisum sativum & $20-30$ & 99 & 98 & & & & \\
\hline 20 & 16232 & Phaseolus vulgaris ..... & $20-30$ & 97. & 98.5 & & & & $(a)$ \\
\hline 21 & 16203 & Fagopyrum fagopyrum. & $20-30$ & 100 & 98.5 & & (b) & (c) & \\
\hline 22 & 16195 & Tritieum aestivum .. & 20 & 99 & 96.5 & & (d) & & (a) \\
\hline 23 & 16186 & Hordeum sativum.. & 20 & 100 & 98 & & (d) & $(d)$ & $(d)$ \\
\hline 24 & 16175 & Avena sativa. & $20-30$ & 70.5 & 91.5 & 95.5 & 0 & 0 & \\
\hline 25 & 16191 & Secale cereale. & 20 & 100 & 98.5 & 88 & 0 & 0 & 0 \\
\hline 26 & 16267 & Cucumis melo....... & $20-30$ & 96. & 97 & 88 & 0 & 0 & 0 \\
\hline 27 & 16199 & Allium cepa......... & $20-30$ & 94. & 88 & 70.5 & 0 & 0 & 0 \\
\hline 28 & 16270 & Lactuca sativa ... & $20-30$ & 100 & 98.5 & 91 & 0 & 0 & 0 \\
\hline 29 & 16281 & Helianthus annuus (cult.).. & $20-30$ & 97 & 96.5 & 43 & 0 & 0 & 0 \\
\hline 30 & 16241 & Linum usitatissimum & $20-30$ & 93.5 & 95 & 83.5 & 0 & 0 & 0 \\
\hline 3 & 16245 & Hibiscus militaris. & $20-30$ & 98.25 & 92 & 94 & 0 & 0 & 0 \\
\hline 32 & 16200 & Asparagus officinalis.. & $20-30$ & 80 & e 69 & 74 & $f 0$ & $f_{0}$ & $f_{0}$ \\
\hline 3 & 16177 & Bromus racemosus. & $20-30$ & 100 & 98.5 & 92.5 & $a_{0}$ & 0 & $a_{0}$ \\
\hline 3 & 16176 & Bromus secalinus.. & $20-30$ & 88.5 & 77 & 95.5 & 0 & 0 & 0 \\
\hline 35 & 16181 & Eleusine indica.... & 35 & 78.2 & 91.5 & 75 & 0 & 0 & 0 \\
\hline 3 & 16284 & Pinus virginiana & $20-30$ & 18 & 6.5 & 43.5 & 0 & 0 & 0 \\
\hline 37 & 16234 & Robinia pseudacacia. & $20-30$ & 14 & $g 11.5$ & 3.5 & 0 & 0 & 0 \\
\hline
\end{tabular}

a Many had germinated and afterwards decayed.

$b$ Approximately 10 per cent had germinated; the remainder had decayed.

$c$ An occasional old sprout was found.

$d$ Approximately all had germinated and afterwards decayed.

e Clipped, 87 per cent; not clipped, 51 per cent.

$f$ Practically all had sprouted; the sprouts from seeds buried at the $36-42$-inch depth were found matted in the bottom of the pot.

$g$ Clipped. 
The corn, sweet corn, corn cockle, cabbage, cotton, peas, beans, buckwheat, wheat, and barley - the first ten samples given in the foregoing table-were all so unmistakably decayed when the seeds were taken up that the contents of the pots were thrown away, no greenhouse tests being made. The first six of these samples showed no trace of any remains of old sprouts; apparently all of the seeds had decayed before germination had taken place. If germination took place it must have been comparatively soon after burial, thus giving ample time for all of the old sprouts to decay beyond identification. This, however, seems hardly probable, considering that the seeds were buried during the latter part of December, 1902; moreorer, the beans, buckwheat, and barley from some or all of the different depths showed clearly the remains of well-dereloped radicles.

The beans which were buried at depths of from 6 to $S$ and from 18 to 22 inches had decared, while many of those buried at a depth of from 36 to 42 inches had germinated and afterwards decayed. The buckwheat from the 6 to $S$ inch depth showed that approximately 10 per cent had germinated, while at 18 to 22 inches there were only the remains of an occasional old sprout, and at 36 to 42 inches all of the seed had decayed. In the wheat the greater number of the grains that were buried from 6 to $S$ and from 36 to $\$ 2$ inches had germinated and then decayed, while those which were buried at a depth of from 18 to 22 inches showed only decayed seed. Approximately all of the barley at the three different depths had germinated and afterwards decayed.

The last fourteen species given in this table were marked "decayed" when the seeds were taken up, but as the conditions were not so clearly indicated as in those first mentioned, germination tests were made in the greenhouse.

The results of the germination tests show that none of the pots contained any viable seeds. Of this latter group only the pots containing: the Asparagus officinalis and Bromus racemosus (Nos. 32 and 33) showed remains of old sprouts. The seeds in the other pots apparently had all decayed without any germination during the time they were buried. The germination of the asparagus seed had been almost perfect. The pot buried at the greatest depth contained only a mass of sproute, many of which were still partially alive. The Bromus racemosus showed that germination had taken place only in the pots buried at 6 to 8 and 36 to 42 inches, while those buried at the depth of 18 to 22 inche had all decayed before germinating.

It is interesting to note in this connection the behavior of the two species of Bromus-Bromus secalinus (cheat or chess) and B. racemirsus (upright chess). The seeds of both of these species had completely lost their vitality within the eleven months in the soil, while the control samples gave a germination of 95.5 and 92.5 per cent, 
respectively. These differences are more clearly shown in Plate I, A and $\mathrm{B}$.

The results abore stated, while perhaps not altogether conclusire, inasmuch as they represent only single tests of 200 seeds in each case, show that seeds of these two plants will not remain viable for long periods when buried in the soil.

This is particularly interesting in the case of the common cheat or chess, which is frequently a pernicious weed in the grain fields of the United States. The generally accepted opinion is that the grains of cheat will live in the soil for a number of years, the seeds germinating when conditions are most farorable, the resulting plants then crowding" out the wheat. Some people even hold that in "off seasons" wheat turns to cheat, but fortunately such erroneous ideas are fast disilppearing.

The results of these experiments show that cheat, whenerer found growing in grain fields or elsewhere, has come from seed recently sown and has not been lying dormant in the soil. With but few exceptions the unexpected appearance of cheat comes either from seeds that have been sown mintentionally mixed with wheat or other gratins so that they passed unobserved, or from seeds that have been scattered with stable manure.

Ir. Beal" has also shown that buried seeds of Bromus secalimus do not retain their vitality for a long period of years. In Beal's experiments the first test was at the expiration of five years, but not a single grain of cheat responded to the germination test at that time.

Table II includes the majority of our more commonly cultivated plant of the field or garden. all of which failed to show any szeds apable of germination after haring been buried in the soil forapproximately one year. This statement will hold good for the majority of our eultivated plant.. There are, howerer, a number of exceptions. Many of these will be found in Table III, some showing that ritality was remarkably well preserved. Of these celery, parsnip, and tobacco (numbers 94, 95, and 99, respectively) should be mentioned in particular. The highest germination in each case was 64 per cent for the celery from the 18 to 22 inch depth, 63 per cent for the parsnip from the 36 to 42 inch depth, and 70 per cent for the tobacco from the 15 to 22 inch depth. 
TabLe III.-Results of tests of seeds that had not completely lost their vitality while buried.

\begin{tabular}{|c|c|c|c|c|c|c|c|c|c|}
\hline \multirow{3}{*}{ 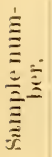 } & \multirow{3}{*}{$\begin{array}{c}\text { Labora- } \\
\text { tory } \\
\text { test } \\
\text { num- } \\
\text { ber. }\end{array}$} & \multirow{3}{*}{ Kind of seed. . } & \multicolumn{3}{|c|}{ Chamber tests. } & \multicolumn{4}{|c|}{ Greenhouse tests in sand. } \\
\hline & & & \multirow{2}{*}{$\begin{array}{l}\text { Tem- } \\
\text { pera- } \\
\text { ture. }\end{array}$} & \multirow{2}{*}{$\begin{array}{c}\text { Origi- } \\
\text { nal- } \\
\text { sample. }\end{array}$} & & & Dep & th of but & al. \\
\hline & & & & & trol. & trol. & $\begin{array}{c}6-8 \\
\text { inches. }\end{array}$ & $\begin{array}{l}18-22 \\
\text { inches. }\end{array}$ & $\begin{array}{l}36-42 \\
\text { inches. }\end{array}$ \\
\hline & & & $\circ C_{.0}$ & Per ct. & Per. ct. & Per ct. & Per ct. & Per ct. & Per ct. \\
\hline $\begin{array}{l}35 \\
39\end{array}$ & $\begin{array}{l}1618.5 \\
1625 \%\end{array}$ & $\begin{array}{l}\text { Festuca elatior .......... } \\
\text { Capsicum annum ..... }\end{array}$ & $\begin{array}{l}20-30 \\
20-30\end{array}$ & $\begin{array}{l}97 \\
96\end{array}$ & $\begin{array}{l}83 \\
97\end{array}$ & $\begin{array}{l}86 \\
80\end{array}$ & $\begin{array}{r}0.5 \\
.0\end{array}$ & $\begin{array}{r}0.0 \\
.0\end{array}$ & $\begin{array}{r}a .0 \\
0\end{array}$ \\
\hline 40 & $1622 \cdot 2$ & Brassica campestris........... & 20 & 90.25 & 86 & 18.5 & .0 & .0 & 6.5 \\
\hline 41 & 16239 & Trifolium repens ............ & 20 & 84.75 & 42.75 & 86 & .0 & $b_{1}$ & 0 \\
\hline 42 & 16210 & Vigna catjang.............. & $20-30$ & 82.5 & 59.5 & 70 & .0 & 1 & .0 \\
\hline 3 & 16230 & Lespedeza frutescens......... & 20 & 15 & $c 1$ & 2.5 & .0 & .0 & 1 \\
\hline 44 & $16^{2}-46$ & Ascyrum hypericoides ........ & 30 & 1.5 & .0 & .0 & 1 & .0 & .5 \\
\hline 45 & 16259 & Lycopersicon lyc & $20-30$ & 99.25 & 72.5 & 88 & .5 & 1 & .5 \\
\hline 46 & 16179 & Chaetochloa glauca .......... & $20-30$ & 55.75 & 37.5 & 18 & 1 & 1 & 1 \\
\hline 47 & 16242 & Rhus glabra $\ldots \ldots \ldots \ldots \ldots \ldots . . . . .$. & $20-35$ & .0 & .0 & $0^{\circ}$ & .0 & 0 & 2 \\
\hline 45 & 16268 & Cucum is sat & $20-30$ & 100 & 98.5 & 62 & 0 & 1 & 3 \\
\hline 49 & 16236 & Trifnlium p & 20 & 89.75 & 73 & 85.5 & 2 & 4 & 4 \\
\hline 50 & $\begin{array}{l}16255 \\
162-1\end{array}$ & Trifolium h & 20 & $\begin{array}{l}91.75 \\
50\end{array}$ & 84 & 73 & 2 & $t$ & 4.5 \\
\hline 51 & $\begin{array}{l}16217 \\
16 \cdot 2029\end{array}$ & $\begin{array}{l}\text { Ranthium pennsylvan } \\
\text { Cassia marylandica... }\end{array}$ & $\begin{array}{l}30 \\
30\end{array}$ & 14.5 & d 98 & $20^{.0}$ & 30 & .0 & .5 \\
\hline $5 \overline{3}$ & 16273 & Ambrosia trifida .............. & $\begin{array}{r}20-30 \\
20\end{array}$ & 29 & 52.5 & 48 & ${ }^{3} 0$ & $\begin{aligned} 3 \\
b \cdot 2\end{aligned}$ & 5 \\
\hline 54 & 16237 & Trifolium pratense $(10964)$.... & 20 & 67.75 & & 70 & 4.5 & 65 & 6 \\
\hline 55 & 16219 & Vaccaria vaccaria.......... & $20-35$ & $e 6.5$ & 88 & $6 S$ & 0 & $b 4$ & $\frac{6}{7}$ \\
\hline 56 & 16251 & Convolvulus sepium & $20-30$ & 4 & 2 & 24 & 2 & 4 & $\frac{7}{7}$ \\
\hline $5 \pi$ & $162 \times 3$ & Rudbeckia hirta... & 30 & 65.5 & 78.5 & 74.5 & 6.5 & 6.5 & $\frac{7}{7}$ \\
\hline 5 s & $16: 24$ & Erysimum cheirantho & $20-35$ & 52.5 & 42 & 14.5 & 2 & 65 & $b \dot{8}$ \\
\hline 59 & $16: 231$ & Medicago sativa .... & & 84.5 & 64.5 & 97 & $b 2$ & $b 9$ & $b 9$ \\
\hline 61) & 16227 & Thlaspi aryense..... & $20-30$ & 57.25 & 54.5 & & $b 1 \overline{1}$ & 8 & 11.5 \\
\hline 61 & $162 t i 1$ & solanum nigrum .. & $20-30$ & 97.75 & 91 & 12 & 9.5 & 10.5 & 12.5 \\
\hline 62 & 16213 & Chenopodium hybridum...... & $20-30$ & 61 & 18.5 & 10.5 & 7.5 & 9.5 & 13 \\
\hline i) 3 & 16253 & Cuscuta polygonorum ....... & $20-30$ & 12 & 8.5 & 55.5 & 11.5 & 10.5 & 13 \\
\hline it & 16193 & siporobolus cryptandrus. . . . . . & 30 & 2.25 & 3 & .0 & & 1.5 & 13.5 \\
\hline 65 & 1626.5 & Plantago rugelii ............ & $20-30$ & 3.75 & 5.5 & 67.5 & 12 & 12 & 13.5 \\
\hline $6 \cos ^{2}$ & $1+; 255$ & Verbena hastata ............ & $20-30$ & 9 & & $\ldots \ldots$ & 11.5 & 13 & 14 \\
\hline 67 & 16220 & Brassica nigra............... & 20 & 1.5 & 13.25 & 34 & 10 & $b 14$ & $b 14$ \\
\hline 68 & $162: 38$ & Trifoliun pratense (hard) .... & .20 & 13.75 & 9.25 & 18 & $b 10.5$ & 15.5 & 14.5 \\
\hline 69 & $161 \times 1$ & Elỵmus triticoides ........... & $20-30$ & 84 & 75 & 85 & 1.5 & b 3.5 & b 15.5 \\
\hline 70 & $1+14 \bar{T}$ & Panicum virgatum.......... & $20-30$ & 30.5 & 36 & 22 & 7 & 17 & 16 \\
\hline 71 & 16174 & Arena fatua ................. & $20-30$ & 70.5 & 91.5 & 93.5 & $b 9$ & $b 8$ & 18 \\
\hline 7.2 & 16211 & Beta rulgaris................. & $20-30$ & 153 & $\ldots \ldots$. & 90 & 7 & 19.5 & 20 \\
\hline 73 & $1+228$ & Potentilla monspelic. & $20-30$ & 41 & $8:$ & 73.5 & $b 9.5$ & 16 & 21.5 \\
\hline $7 \pm$ & $1+i 1 \times 3$ & Elymus canadensis........... & $20-30$ & 93.5 & 9.5 .5 & 81 & .0 & $b 7$ & $b 22$ \\
\hline 7.5 & 16190 & Pua pratensis......... & $20-30$ & 90.75 & 87 & 59 & 16 & 22 & 24.5 \\
\hline 76 & 16262 & Verbascum thapsus. & $20-30$ & 82.3 & 98 & 72.5 & 7 & 7.5 & 25.5 \\
\hline 27 & 16182 & Elymus virginicus..... & $20-35$ & 6.5 .2 & 44 & 83 & a.2 & $b 13.5$ & b25.5 \\
\hline is & 16226 & Sis ymbrium altissimum . & 20 & 88.25 & 86.25 & 76 & $b 10.5$ & 17. & 26 \\
\hline 79 & 16256 & Verbena urticifolia...... & 30 & $1 . \overline{5}$ & & 56.5 & 23.5 & 24. & 26.5 \\
\hline$\therefore 0$ & $16 ; 27$ & Carduus arvensis...... & $20-30$ & 56.75 & 68 & 5 & 21 & 22.5 & 28.5 \\
\hline$\$ 1$ & 162.52 & oea lacunosa.... & $20-35$ & 98.5 & $f 88$ & 88 & 20 & 25 & 33 \\
\hline$\times 2$ & 16,254 & Cuscuta epilin & $20-30$ & & & 5 & 15.5 & 23.5 & 34 \\
\hline$\therefore 3$ & 10214 & inthus retroflexus. & $20-30$ & 94.75 & 91 & 61 & 18 & 22 & 35 \\
\hline-4 & $16: 276$ & Bidens frondosa . . . . . . . . . . . & $20-30$ & 75 & 52.5 & 25 & 29 & 33 & 36 \\
\hline 8.5 & 1620.5 & Neslia praniculata... & $20-3.5$ & 96 & 97 & 68 & 23 & 24.5 & 38.5 \\
\hline 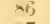 & $16: 16$ & Portulaca oleracea. & 35 & 83.75 & 91. & 16 & 39 & 38.5 & 30.5 \\
\hline 87 & 16272 & Ambrosia artemisiaef & $20-30$ & 58.5 & 42.5 & 30. & 32 & 37 & 41 \\
\hline-8 & $16 \geq 63$ & Plantag() lancerslata... & 30 & 82. & 78 & 67 & 41 & 41 & 41 \\
\hline$\times 9$ & 16279 & Grindelia squa rrosa. & $20-30$ & 25.7 & 41 & 87. & 30.5 & 36 & 42 \\
\hline 90 & 16,71 & Taraxacum erythrospermum . & $20-30$ & 8.5 .7 & 87.5 & 8.5 .5 & 35. & 41. & 45.5 \\
\hline 91 & $16 \div-4 ;$ & 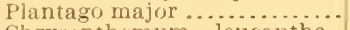 & $20-30$ & 24 & 78 & .0 & 39.5 & 43.5 & 46.5 \\
\hline 92 & & $\begin{array}{l}\text { Chrysunthemum leucanthe- } \\
\text { mium }\end{array}$ & & 25 & 91 & & & & \\
\hline 93 & 16188 & Phalaris arunrlinacea. & $20-35$ & 69.25 & 8 & 78 & 45 & 46.5 & 56.5 \\
\hline 94 & 16248 & Apium graveolens....... & $20-30$ & 88 & 83. & 72. & 48.5 & 64 & 60 \\
\hline 9.5 & $16: 219$ & Pastinaca sativa...... & $20-30$ & 5.5 .5 & 67 & 78. & 29 & 51 & 63 \\
\hline $9+;$ & $16: 212$ & Chenoprorlium albun & $20-30$ & 67.25 & 58 & 33.5 & 32 & 63.5 & 64.5 \\
\hline 97 & 16280 & Helianthus annuus (wild) .... & $20-30$ & 100 & 97 & $86^{\circ}$ & 43.5 & 64 & 66.5 \\
\hline 95 & $16.26,9$ & Lactuca scariola.............. & 00 & 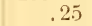 & 11. & $\times 3$ & 63.5 & 69 & 69.5 \\
\hline 99 & 16260 & Nicotiana tabacum...... & $20-30$ & 89.25 & 81.2 & 89. & 46.5 & 70 & 55 \\
\hline & 16173 & Agropyron repens ... & $20-30$ & 80.24 & 84 & 23.5 & 20.5 & $b 73$ & 66.5 \\
\hline & 16275 & A retium lappa.. & $20-30$ & 99.75 & 96 & $\times 8.5$ & 42.5 & 63.5 & 73 \\
\hline & $16 ; 209$ & Rumex obtusifolius. & $20-30$ & 97.5 & 95.5 & 80 & 73 & 72.5 & 79.5 \\
\hline & 16268 & Rumex crispus ...... & $20-30$ & 80.75 & 83.5 & 91 & 67.5 & 79.5 & 79 \\
\hline 4 & 16,215 & Phytolac'a americana... & $20-30$ & 40.5 & $d \times 8.5$ & 84.5 & 7.5 & 66.5 & 80.5 \\
\hline 5 & $16 ; 250$ & Fraxinus americanus......... & $20-30$ & 49.5 & 2 & 26 & & .0 & 84 \\
\hline 68 & $16,25 x$ & 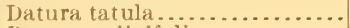 & $20-30$ & 99 & $r 54$ & 88 & $b 86$ & 84 & 86.5 \\
\hline & 16,207 & Rumex salicifolius . & $20-30$ & 98.25 & 96.5 & 2.5 & 88.5 & 85.5 & 70.5 \\
\hline & 16178 & r'haetochloa verticillata ...... & $20-30$ & 92.75 & 94.5 & 88.5 & $b .58$ & 71 & 90 \\
\hline & 16,282 & (jnoperrlon acanthium ........ & $20-30$ & 95.5 & 31 & .0 & 86 & 93 & 90.5 \\
\hline
\end{tabular}


TABLE III.-Results of tests of seeds that had not completely lost their vitality while. buried-Continued.

\begin{tabular}{|c|c|c|c|c|c|c|c|c|c|}
\hline \multirow{3}{*}{ 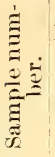 } & \multirow{3}{*}{$\begin{array}{c}\text { Labora- } \\
\text { tory } \\
\text { test } \\
\text { num- } \\
\text { ber. }\end{array}$} & \multirow{3}{*}{ Kind of seed. } & \multicolumn{3}{|c|}{ Chamber tests. } & \multicolumn{4}{|c|}{ Greenhouse tests in sand. } \\
\hline & & & \multirow{2}{*}{$\begin{array}{l}\text { Tem- } \\
\text { pera- } \\
\text { ture. }\end{array}$} & \multirow{2}{*}{$\begin{array}{c}\text { Origi- } \\
\text { nal } \\
\text { sample. }\end{array}$} & \multirow{2}{*}{$\begin{array}{l}\text { Con- } \\
\text { trol. }\end{array}$} & \multirow{2}{*}{$\begin{array}{l}\text { Con- } \\
\text { trol. }\end{array}$} & \multicolumn{3}{|c|}{ Depth of burial. } \\
\hline & & & & & & & $\begin{array}{c}6-8 \\
\text { inches. }\end{array}$ & inches. & \begin{tabular}{|c|}
$36-42$ \\
inches.
\end{tabular} \\
\hline \multirow{3}{*}{$\begin{array}{l}110 \\
111 g \\
112 g\end{array}$} & \multirow{3}{*}{$\begin{array}{l}16218 \\
16243 \\
16189\end{array}$} & Alsine media & $\begin{array}{l}\circ{ }^{\circ} . \\
20-30\end{array}$ & $\underset{97}{\text { Per }}$ ct. & $\begin{array}{c}\text { Per ct. } \\
98.5\end{array}$ & $\underset{93}{\text { Per ct. }}$ & $\begin{array}{r}\text { Per ct. } \\
90.5\end{array}$ & $\begin{array}{l}\text { Per ct. } \\
96.5\end{array}$ & $\begin{array}{l}\text { Per ct. } \\
\quad 92.5\end{array}$ \\
\hline & & $\begin{array}{l}\text { Abutilon abutilon } \\
\text { Phleum pratense. }\end{array}$ & & & & & & & \\
\hline & & $\begin{array}{c}\text { Average percentage of } \\
\text { germination ............ }\end{array}$ & & 63.2 & 57.5 & 53.2 & 20.5 & 26.5 & 31 \\
\hline
\end{tabular}

a Many had'germinated and afterwards decayed.

$b$ Fresh sprouts found when samples were taken up. These sprouted seeds were not thrown away, but were transplanted with the remainder of the sample and tested in sand in greenhouse, consequently those which produced seedlings are included in the percentages of germination given in the table. These fresh sprouts were found as follows:

\begin{tabular}{|c|c|c|c|c|c|c|c|c|c|c|c|}
\hline $\begin{array}{l}\text { Sam- } \\
\text { ple } \\
\text { num- } \\
\text { ber. }\end{array}$ & Depth. & Sprouts. & $\begin{array}{c}\text { Sam- } \\
\text { ple } \\
\text { num- } \\
\text { ber. }\end{array}$ & Depth. & Sprouts. & $\begin{array}{c}\text { Sam- } \\
\text { p!e } \\
\text { num- } \\
\text { ber. }\end{array}$ & Depth. & Sprouts. & $\begin{array}{l}\text { Sam- } \\
\text { ple } \\
\text { num- } \\
\text { ber. }\end{array}$ & Depth. & Sprouts. \\
\hline $\begin{array}{l}39 \\
53 \\
54 \\
55 \\
58 \\
58 \\
59 \\
59\end{array}$ & $\begin{array}{r}\text { Inches. } \\
36-12 \\
18-22 \\
1 \times-22 \\
18-22 \\
18-22 \\
36-12 \\
6-8 \\
18-22\end{array}$ & $\begin{array}{r}1 \\
3 \\
1 \\
1 \\
10 \\
5 \\
4 \\
2\end{array}$ & $\begin{array}{l}59 \\
60 \\
67 \\
67 \\
68 \\
69 \\
69 \\
71\end{array}$ & $\begin{array}{r}\text { Inches. } \\
36-42 \\
6-8 \\
18-2 \cdot 2 \\
36-42 \\
6-8 \\
18-22 \\
36-42 \\
6-8\end{array}$ & $\begin{array}{r}1 \\
1 \\
2 \\
2 \\
1 \\
\text { Few. } \\
\text { Many. } \\
\text { Many. }\end{array}$ & $\begin{array}{l}71 \\
73 \\
74 \\
74 \\
77 \\
77 \\
78 \\
92\end{array}$ & $\begin{array}{r}\text { Inches. } \\
18-22 \\
6-8 \\
18-22 \\
36-42 \\
18-22 \\
36-42 \\
6-8 \\
6-8\end{array}$ & $\begin{array}{r}\text { Many. } \\
4 \\
\text { Few. } \\
\text { Many. } \\
10 \\
5 \\
1 \\
\text { Many. }\end{array}$ & $\begin{array}{r}92 \\
92 \\
100 \\
106 \\
108\end{array}$ & $\begin{array}{c}\text { Inches. } \\
18-22 \\
36-42 \\
18-22 \\
6-8 \\
6-8\end{array}$ & $\begin{array}{l}\text { Many. } \\
\text { Many. } \\
\text { Many. }\end{array}$ \\
\hline
\end{tabular}

c Clipped seed germinated, 59 per cent. aclipped.

e Germinated, 84 per cent at $20^{\circ} \mathrm{C}$.

$f$ Clipped seed germinated, 100 per cent.

$g$ Tests interrupted.

In Table III the names of the seeds are arranged in the order of their ritality as determined by the germination tests made in the greenhouse. The list of seeds tested begins with Festuca elation (meadow fescue), which showed only one viable seed, that being from the 18 to 22 inch depth, and ends with Alsine media (common chickweed), in which nearly all of the seeds retained their power of germination throughout the entire period that they remained in the soil. The germination of the latter, when sown in the greenhouse, was almost perfect. (See Pl. II, fig. 1.)

In many instances some of the seeds had germinated while they were buried. In most cases the seeds which had germinated afterwards decayed. In the larger seeds this could usually be determined without much difficulty, but with many of the smaller seeds no such obserrations could be made. However, it is more than probable that many of the smaller seeds which showed a low germination when transplanted in the greenhouse had germinated and afterwards decayed before being dug up, but this could not be satisfactorily determined by a hurried field examination. Many of the pots also contained fresh 
sprouts at the time the seeds were taken up. The number of fresh sprouts in each case is indicated in a footnote to Table III.

Unlike Table II, Table III includes names of but very few of our cultirated plants. The majority belong to that class of plants commonly known as weeds. These results show that but a limited number of our cultivated plants produce seeds which can retain their vitality for any length of time when buried in soil. On the other hand, the seeds of the plants which are commonly known as weeds are . of strong vitality, and many of them deteriorated but very little with the treatment given. This, of course, is what we would expect. By natural selection the wild plants which survive are just those from seeds which are capable of living in the soil for a period of time more or less extended, and ultimately this factor becomes hereditary. With most of the cultivated plants the seeds are gathered and carefully saved firom rear to year, resulting in the loss of these inherited characteristics.

The mere fact that certain seeds retain their power of germination for a period of years when buried in the soil brands the plants which they produce as weeds. The length of time that such seeds can remain in the soil and still retain their power of germination largely determines their noxiousness. In other words, it may well be said that the pernicious character of weeds is directly proportional to the length of time the seeds will remain viable when buried in the soil. For this reason bad weeds are difficult to eradicate once the seeds are allowed to mature. (See Pl. II.)

\section{RELATION OF DEPTH OF BURIAL TO VITALITY.}

Table III shows that many of the seeds were better preserved the deeper they were buried. This is probably best explained by the difference in the three factors which govern germination, viz, heat, moisture, and oxygen. At the greatest depth the amount of moisture is alwars more uniform, the supply of air is greatly lowered, and the temperature is much reduced. The temperature decreases very rapidly as we go below the surface of the soil, and at $3 \frac{1}{2}$ feet is comparatively uniform throughout the year. Experiments conducted at MeGill College, Montreal, Canada, by C. H. McLeod show that at a depth of 40 inches below the surface of the soil the minimum and maximum temperatures through the year were approximately $35^{\circ}$ and $60^{\circ} \mathrm{F}$., respectively. ${ }^{a}$

The greater number of seeds germinate best when subjected to daily alternations in temperature. These alternations do not take place at a depth of 3 feet below the surface; consequently there is a better

a Trans. Roy. Soc., Canada, Ser. 2, Vol. 7, Sec. III, pp. 13-16, 1901. 
preservation of vitality at that depth as a result of the more dormant condition of the seeds. (See Pl. III and the diagram below.)

As was anticipated, most of the seeds which were stored in the Seed Laboratory preserved their vitality much better than those that were buried. But there are a number of cases in which the seeds were preserved practically as well in the soil as in the laboratory, the deterioration being very small in either case. However, with but few exceptions, an ample number of seeds remained germinable at the termination of the first year to produce plants in sufficient number to keep the up-to-date farmer busy for a good share of the summer in suppressing them. The average percentages of germination of all samples, including the original test and both controls, are best shown in the following diagran:

Average germination of controls and buried seeds.

Original tests, 63.2 per cent.

Controls (chamber), 57.5 per cent.

Controls (greenhouse), 53.2 per cent.

Buried 6-8 inches, 20.5 per cent.

Buried 18-2.2 inches, 26.5 per cent.

Buried 36-42 inches, 31 per cent.

\section{HARD SEEDS.}

An interesting point in these first results is in the hehavior of the Trifoliums and closely related genera, including Lespedeza and Medicago. Generally speaking, these seeds are considered to be able to withstand very critical treatment, but the results of the first year's experiments show that the seeds of all of these deteriorated very greatly while in the soil.

The white clover, No. 41, germinated only 1 per cent, and showed one fresh sprout when taken up from the 18 to 22 inch depth and nothing from the shallower or deeper trenches. The red clover did but little better; No. 49, a sample of the harvest of 1902, germinated 2,4 , and 4 per cent for the three different depths of 6 to 8,18 to 22 , and 36 to 42 inches, respectively. Another sample of red clover, No. 54 , germinated $4.5,5$, and 6 per cent, respectively, for the three different depths. A third sample of red clover, No. 68, gerninated $10.5,15.5$, and 14.5 per cent, respectively, from the three depths. The last two samples were of Oregon-grown seed of the harvest of 1900 . The original sample of this seed, No. 54, contained 51.5 per cent of 
hard seed. No. 68 includes only the hard seed selected from the Oregon clover by soaking in water for 18 and then for 20 hours a portion of the original bulk sample, using only the remaining hard seed.

These results, while unsatisfactory, show clearly that it is the hard seeds in the clovers which remain over in the soil for some considerable time. The alsike clover, No. 50, behaved practically the same as the sample of red clorer first mentioned. The Lespedeza, or bush clover, No. 43 , gave results very similar to the white clover. The alfalfa, No. 59, gave a germination of only 2, 9, and 9 per cent, respectively, for the three different depths. But in all cases a few fresh sprouts were present when the seeds were taken up, showing that the seeds were germinating and afterwards decaying.

\section{SEEDS OF CULTIVATED VERSUS WILD PIANTS.}

A number of interesting cases showing the greater hardiness of the seeds of wild plants orer those of like or closely related cultivated forms were recorded. In Ilelienthus anmus. (Nos. 6 and 97) the seeds from the cultivated plant-our common sunflower of the garden--all decayed, while the seeds of the wild sunflower retained their vitality and germinated $43.5,64$, and 66.5 per cent, respectively, for the three different depths. Similarly with Lactuca sativa and Lactuca scariola, Nos. 5 and 95 , respectively, the common garden lettuce seed had all decayed, while the seed of the prickly lettuce, possibly the parent of our cos varieties, germinated $63.5,69$, and 69.5 per cent, respectively, for the three different depths. Another striking example is in Avena sativa, No. 1, and Avem futua, No. 71, the latter germinating 9, 8, and 18 per cent, respectively, for the three different depths, besides showing many fresh sprouts in the two shallower depths at the time the seeds were taken up.

Furthermore, it is not uncommon to find wide variations in different species of the same genus, even where all forms are wild, e. g., Elymus, Chaetochloa, Chenopodium, Cuscuta, Plantago, etc. But in the cases above mentioned of the cultivated and the closely related wild forms the ability of the seeds to withstand such treatment as being buried in the soil has been lost by long cultivation of the plants and the careful preservation of the seeds under artificial conditions or storage, while seeds from the wild forms can survive when buried in the soil, for it is the plants from just such seeds that have survived.

\section{SUMMARY.}

The length of time that seeds will retain their vitality when buried in the soil is of much importance in the extermination of weeds.

The seeds of many of our pernicious weeds can be destroyed hy deep plowing, if the soil is left undisturbed for some time. 
Seeds of the cultivated plants, with but few exceptions, lose their vitality when buried in the soil.

Seeds of the plants commonly designated as weeds retain their vitality remarkably well when buried in the soil.

In general, the pernicious character of weeds is directly proportional to the length of time the seeds will remain viable when buried in the soil.

The deeper seeds are buried, the better is vitality preserved.

Hard seeds of the same species retain their vitality much better than those with softer seed coats.

Unhulled seed, especially of the grasses, is more resistant than hulled seed, and the vitality is always better preserved.

Seeds of plants from the same genus often retain their vitality in a very different degree.

Vitality is best preserved, even in weed seeds, when the seeds are carefully harvested and stored in a dry and comparatively cool place. 
P L A TES. 


\section{DESCRIPTION OF PLATES.}

Plate I. Fig. 1.-Bromus racemosus, smooth brome grass. Fig. 2.-Bromus secalinus, cheat or chess. The two divisions at the right of each figure show the vigorous growth marle by the check samples. In the three divisions at the left, A, B, and $\mathrm{C}$, were planted the seeds which had been buried at depths of 6 to 8 inches, 18 to 22 inches, and 36 to 42 inches, respectively. The vitality of the seeds of these two species, which are considered as noxious weeds in the grain fields of the United States, was destroyed at the expiration of eleven months.

Plate 1I. Fig. 1.-Alsine media, common chickweed. Fig. 2. - Rumex crispus, curled dock. Fig. 3.-Datura tutula, jimson weed. Seedlings from weed seeds which dicl not lose their vitality by burial for eleven months, as shown in the three divisions at the left of each flat, the germination being practically the same as in the case of the two check samples shown at the right of each flat.

P'LATE III. Fig. 1.-Elymus canadensi, nodding wild rye. A, buried 6 to 8 inchesall killed; $\mathrm{B}$, buried 18 to 22 inches-only one seedling shows in the figure, but the total germination was 7 per cent, as given in the table; C, buried 36 to 42 inches-germinated 22 per cent; the two check samples at the right made vigorous growth, germinating 81 per cent. Fig. 2. - Fraxinus americums, white ash. A, buried 6 to 8 inches, and $\mathrm{B}$, buried 18 to 22 inches-all killed; C, buried 36 to 42 inches-germinated 84 per cent; the check samples germinated 26 per cent, but the seedlings had "damped off" before the photograph was taken. Fig. 3.-Plyytolacea americana, poke. A, buried 6 to 8 inches-germinated 7.5 per cent; B, buried 18 to 22 inches-germinated 60.5 per cent; C, buried 36 to 42 inches-germinated 80.5 per cent; the two check samples germinated 84.5 per cent.

The illustrations show that in many cases the vitality of seeds is better preserved at a depth of 36 to 42 inches than at shallower depths.

22 


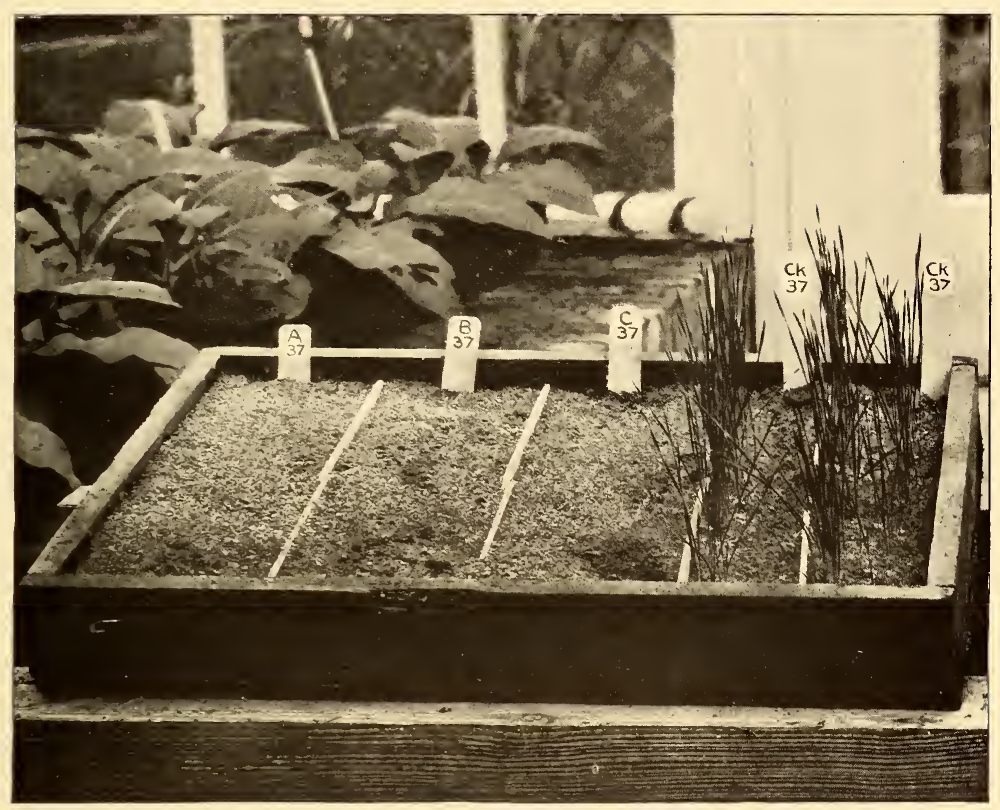

Fig. 1.-Bromus Racemosus (Smooth Brome-Grass).

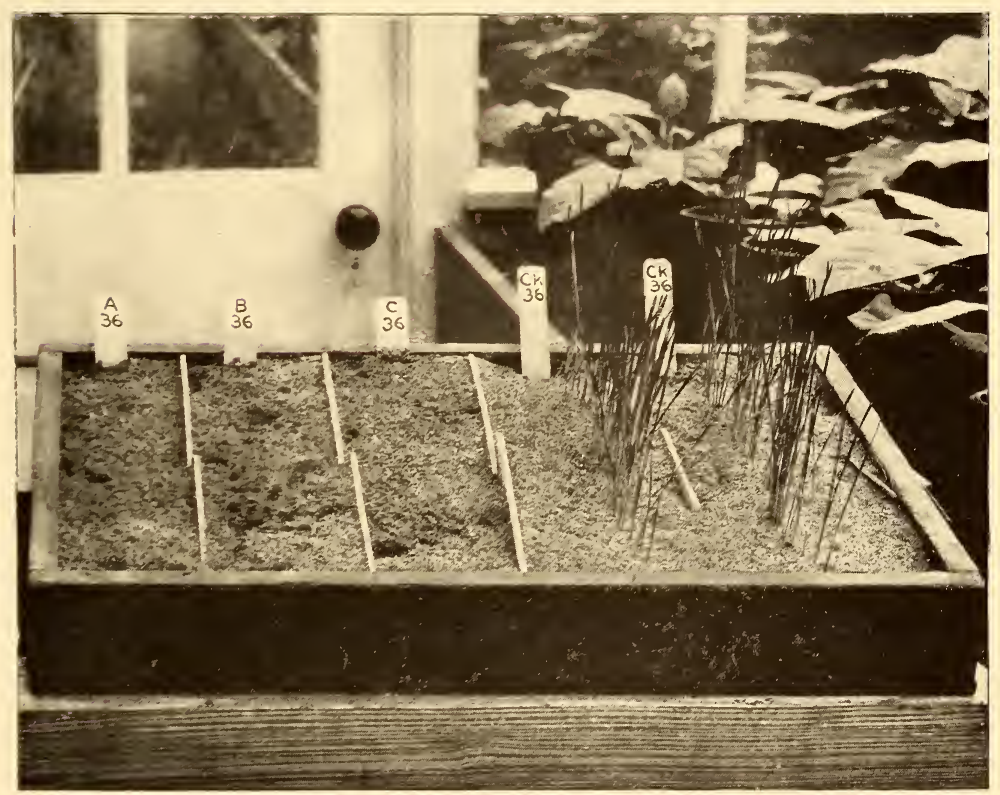

Fig. 2.-Bromus Secalinus (Cheat, or Chess). 



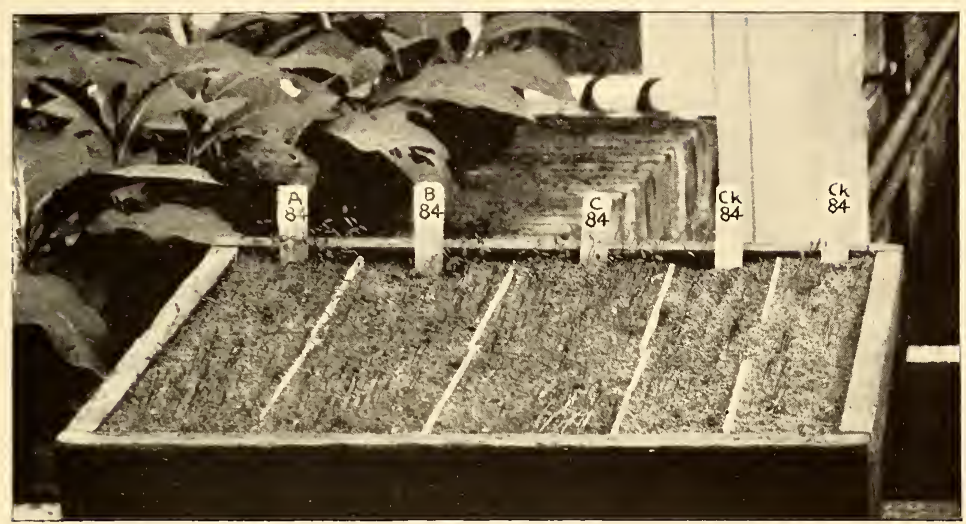

Fig. 1.-Alsine Media (COMmon Chickweed).

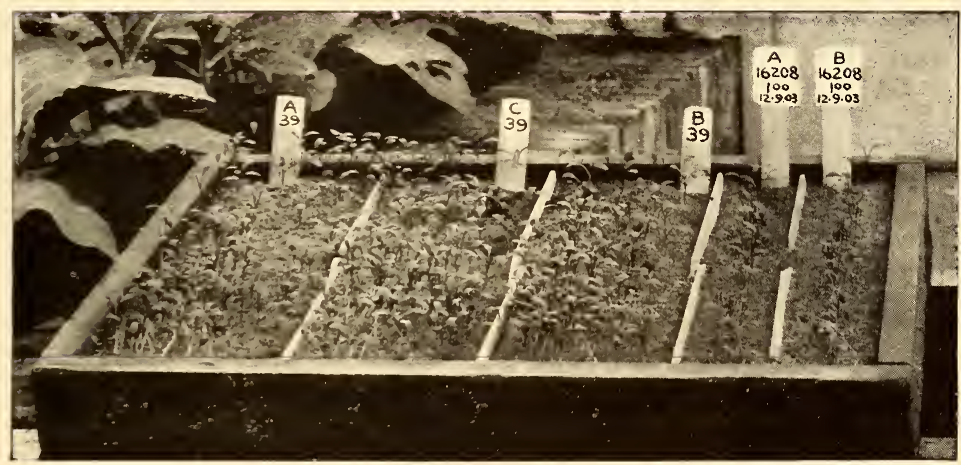

Fig. 2.-RUMEX CRISPUS (CURLED DOCK).

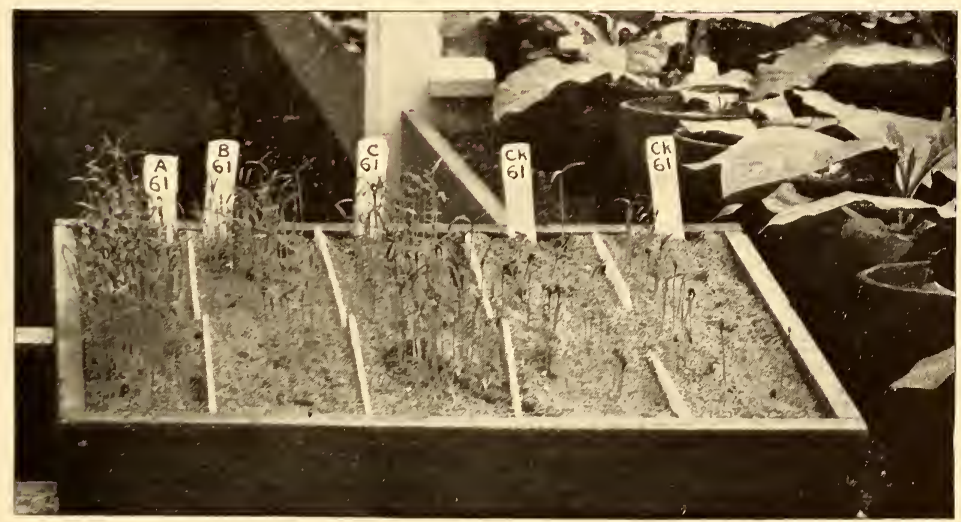

Fig. 3.-Datura tatula (Jimson Weed). 



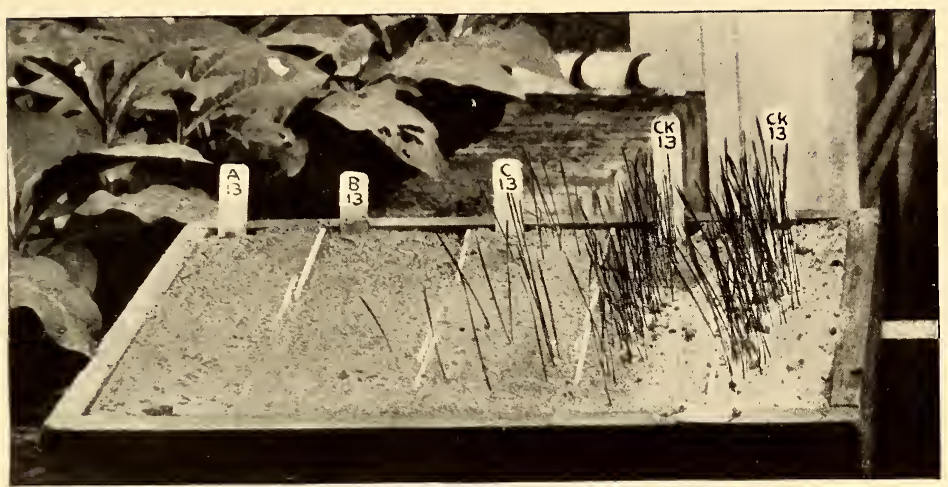

Fig. 1.-Elymus Canadensis (Nodding Wild Rye).

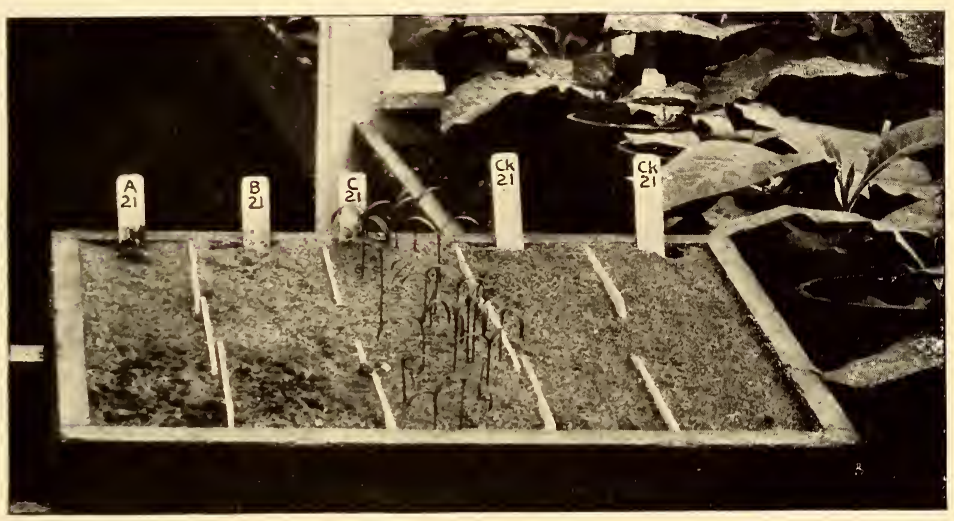

Fig. 2.-Fraxinus americana (White Ash).

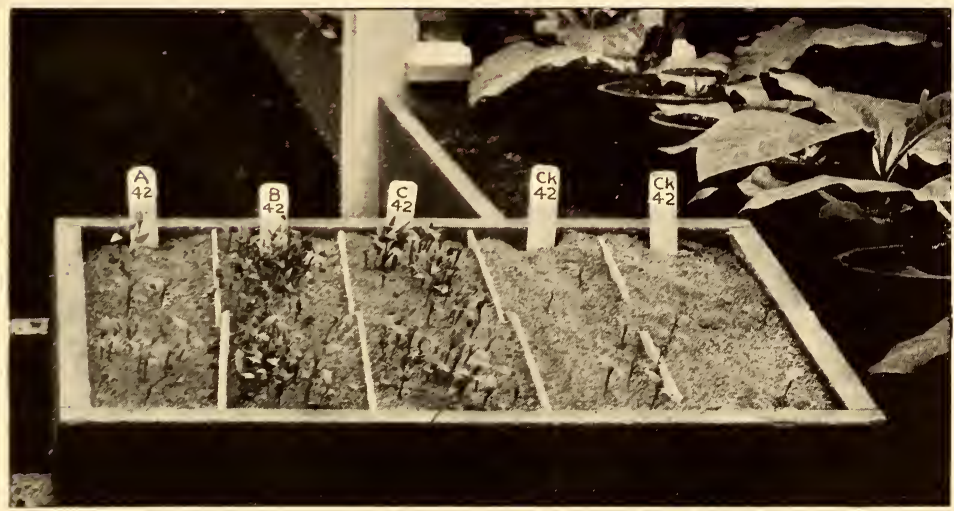

Fig. 3.-Phytolacca Americana (Poke). 



No. 33. North American Species of Leptochloa. 1903. Price, 15 cents.

34. Silkworm Food Plants. 1903. Price, 15 cents.

35. Recent Foreign Explorations. 1903. Price, 15 cents.

36. The "Bluing" and the "Red Rot" of the Western Yellow Pine, with Special Reference to the Black Hills Forest Reserve. 1903. Price, 30 cents.

37. Formation of the Spores in the Sporangia of Rhizopus Nigricans and of Phycomyces Nitens. 1903. Price, 15 cents.

38. Forage Conditions and Problems in Eastern Washington, Eastern Oregon, etc. 1903. Price, 15 cents.

39. The Propagation of the Easter Lily from Seed. 1903. Price, 10 cents.

40. Cold Storage, with Reference to the Pear and Peach. 1903. Price, 15 cents.

41. The Commercial Grading of Corn. 1903. Price, 10 cents.

42. Three New Plant Introductions from Japan. 1903. Price, 10 cents.

43. Japanese Bamboos. 1903. Price, 10 cents.

44. The Bitter Rot of Apples. 1903. Price, 15 cents.

45. The Physiological Rôle of Mineral Nutrients in Plants. 1903. Price, 5 cents.

46. The Propagation of Tropical Fruit Trees and Other Plants. 1903. Price, 10 cents.

47. The Description of Wheat Varieties. 1903. Price, 10 cents.

48. The Apple in Cold Storage. 1903. Price, 15 cents.

49. The Culture of the Central American Rubber Tree. 1903. Price, 25 cents.

50. Will Rice: Its Uses and Propagation. 1903. Price, 10 cents.

51. Miscellaneous Papers: I. The W'ilt Disease of Tobacco and Its Control. II. The Work of the Community Demonstration Farm at Terrell, Tex. III. Fruit Trees Frozen in 1904. IV. The Cultivation of the Australian Wattle. V. Legal and Customary Weights per Bushel of Seeds. VI. Golden Seal. 1905. Price, 5 cents.

52. Wither-Tip and Other Diseases of Citrous Trees and Fruits Caused by Colletotrichum Gloeosporioides. 1904. Price, 15 cents.

53. The Date Palm. 1904. Price, 20 cents.

54. Persian Gulf Dates. 1903. Price, 10 cents.

55. The Dry Rot of Potatoes. 1904. Price, 10 cents.

56. Nomenclature of the Apple. 1905. Price, 30 cents.

57. Methorls Used for Controlling Sand Dunes. 190t. Price, 10 cents.

58. The Vitality and Germination of Seeds. 1904. Price, 10 cents.

59. Pasture, Meadow, and Forage Crops in Nebraska. 1904. Price, 10 cents.

60. A Soft Rot of the Calla Lily. 190t. Price, 10 cents.

61: The Avocado in Florida. 1904. Price, 5 cents:

62. Notes on Egyptian Agriculture. 1904. Price, 10 cents.

63. Investigations of Rusts. 1904. Price, 10 cents.

64. A Method of Destroying or Preventing the Growth of Algæ and Certain Pathogenic Bacteria in Water Supplies. 1904. Price, 5 cents.

65. Reclamation of Cape Cod Sand Dunes. 1904. Price, 10 cents.

66. Seeds and Plants Imported. Inventory No. 10. 1905. Price, 20 cents.

67. Range Investigations in Arizona. 1904. Price, 15 cents.

68. North American Species of Agrostis. 1905. Price, 10 cents.

69. American Varieties of Lettuce. 1904. Price, 15 cents.

70. The Commercial Status of Durum Wheat. 1904. Price, 10 cents.

71. Soil Inoculation for Legumes. 1905. Price, 15 cents.

72. Miscellaneous Papers: I. Cultivation of Wheat in Permanent Alfalfa Fields. II. The Salt Water Limits of Wild Rice. III. Extermination of Johnson Grass. IV. Inoculation of Soil with Nitrogen-Fixing Bacteria. 1905. Price, 5 cents.

73. The Development of Single-Germ Beet Seed. 1905. Price, 10 cents.

74. The Prickly Pear and Other Cacti as Food for Stock. 1905. Price, 5 cents.

75. Pange Management in the State of Washington. 1905. Price, 5 cents.

76. Copper as an Algicide and Disinfectant in Water Supplies. 1905. Price, 5 cents.

77. The Avocarlo, a Salad Fruit from the Tropies. 1905. Price, 5 cents.

78. Improving the Quality of Wheat. [In press.]

79. The Variability of Wheat Varieties in Resistance to Toxic Salts. [In press.]

80. Agricultural Explorations in Algeria. [In press.]

81. Evolution of Cellular Structures. [In press.]

82. Grass Lands of the South Alaska Coast. [In press.] 

Binder

Gaylord Bros., Inc.

Makers

Syracuse, N. Y. PAT. JAN 21. 1908
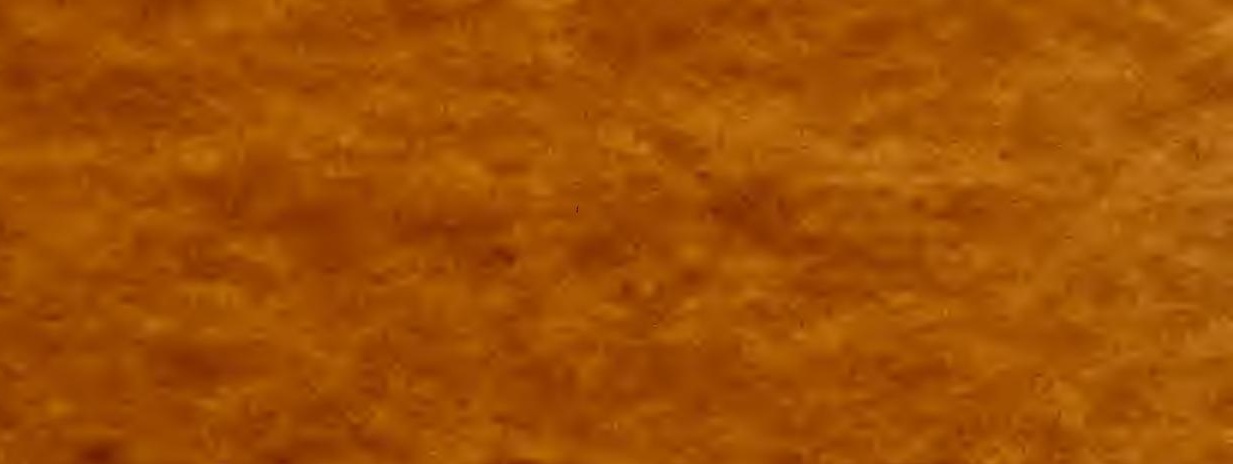
4

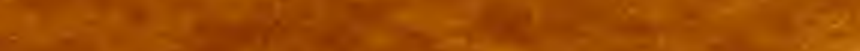

ir
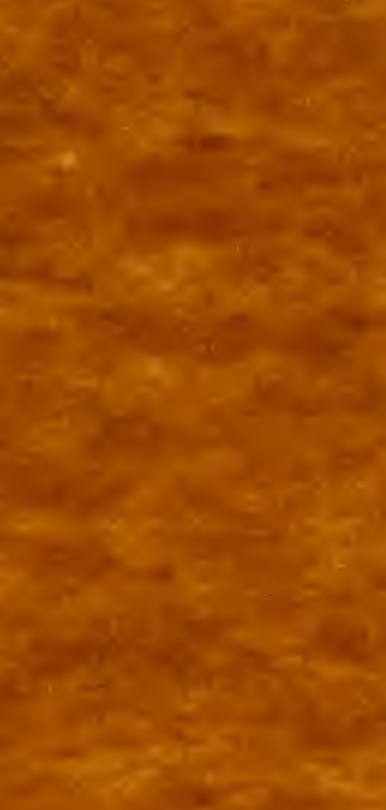
SMITHSONIAN INSTITUTION LIBRARIES 